\title{
Effect of protein and energy levels in a constant ratio supplemented with methionine and lysine on performance of layers and on egg quality
}

\author{
A. R. El Boushy, L. G. M. van Gils ${ }^{1}$ and M. C. Papadopoulos 2 \\ Department of Poultry Husbandry, Agricultural University, $6700 \mathrm{AH}$ Wageningen, \\ the Netherlands
}

Received: 30 March 1979; accepted 17 September 1979

Key words: laying hen, protein energy level, methionine, lysine, performance, egg quality

\section{Summary}

Medium-heavy layers were housed in batteries with a constant environment, 720 hens in all. Each treatment was composed of 36 hens replicated four times. Five rations were prepared with increasing protein and energy levels in constant ratio and in equal steps from $12 \%$ crude protein $(\mathrm{CP})$ and $8.71 \mathrm{MJ} / \mathrm{kg}$ metabolizable energy (ME) to $16 \% \mathrm{CP}$ and $11.70 \mathrm{MJ} / \mathrm{kg} \mathrm{ME}$.

1. Egg production and egg weight were not significantly affected by the several energy and protein treatments.

2 . Increasing the nutrient density of the ration decreased feed consumption, increased body weight and improved feed conversion, significantly.

3. Dietary treatments had no significant effect on egg quality as indicated by egg weight $(\mathrm{g})$ and proportions of yolk, albumen and shell.

4. By increasing the dietary levels of protein and energy, daily intake of crude protein and energy increased, and daily intake of sulphur amino acids decreased.

\section{Introduction}

In the last years, many investigations have been conducted about protein and energy requirements of laying hens. However, few studies have been reported on proteinenergy interrelationships with performance of laying hens.

That egg production is unaffected by dietary energy level is an assumption supported by the great majority of published evidence (reviewed by Morris, 1968). Aitken et al. (1973) found that protein level was the dietary factor that contributed

1 Present address: Trouw \& Co. NV International, Putten, the Netherlands.

2 Present address: Poultry Production Organization, Ioannina, Greece. 
most to large real effects of ration on egg production. Quisenberry (1965) presented evidence (with isocaloric diets) showing that methionine supplementation, as the first limiting amino acid in a laying ration, consistently improved protein conversion ratios in low-protein diets for the laying hen. Johnson \& Fisher (1959) reported that a diet with $10.4 \%$ protein and added methionine and lysine supported egg production as well as a diet containing $15.7 \%$ protein. Fernandez et al. (1973) reported that a diet with $13 \%$ protein and supplemented with lysine and methionine was as effective as one with 15,17 and $18 \%$ protein (in isocaloric rations) for egg production and egg size.

Egg weight was increased when 'high energy' diets were offered (Morris, 1968) or when metabolizable energy intake was increased (De Groote, 1972).

Dietary protein, energy, weight and volume have all been found to exert a significant linear effect upon feed consumption of laying hens, according to the findings of Gleaves et al. (1968). Morris (1968) concluded that the ability of layers to regulate daily energy intake decreased as the energy content of the diet increased, while Aitken et al. (1973) observed that feed consumption was influenced by protein and energy levels.

Body weight was slightly greater with high-energy diets (Morris, 1968). Aitken et al. (1973) showed that protein level was the dietary factor most closely associated with large effects of ration on body weights gains, while Fernandez et al. (1973) found a variable effect of protein level on body weight gains of hens.

Thornton \& Whittet (1959) concluded that feed efficiency in diets of $13 \%$ crude protein (CP) was comparable to 15 and $17 \% \mathrm{CP}$, with several levels of energy. Reid (1976) working with isocaloric diets with from 10 to $19.5 \%$ protein, showed that feed conversion was significantly poorer only in the two lower-protein diets (10 and $11.5 \%$ ).

For egg quality, Smith (1965) showed that there was a tendency toward higher interior egg quality, as measured by Haugh unit score, with the low-protein (11\%) diet was fed compared to 15 and $19 \%$ protein.

The objective of the present study was to determine the influence of diets with a series of energy and protein levels in a constant ratio, on laying performance and egg characteristics.

\section{Material and methods}

The trial involved 720 medium-heavy layers from a cross of two strains developed at the Department. All hens were housed in batteries, each in a single cage and with one through for 3 hens. Layers were kept in a constant environment $\left(10^{\circ} \mathrm{C}\right.$ and $80 \%$ r.h.) with 14 hours artificial light daily. Each treatment was composed of 36 hens replicated four times. The experimental treatments consisted of five rations (Tables 1 and 2). The rations were composed in such a way that protein and energy contents increased in a constant ratio with equal steps from $12 \%$ crude protein and $8.71 \mathrm{MJ} / \mathrm{kg}$ metabolizable energy (ME) in Ration 1 to $16 \%$ crude protein and $11.70 \mathrm{MJ} / \mathrm{kg} \mathrm{ME}$ in Ration 5. Vitamins, minerals, methionine and lysine were added to meet the requirements. 
Table 1. Composition (\%) of experimental diets.

\begin{tabular}{|c|c|c|c|c|c|}
\hline Ingredient & $\begin{array}{l}\text { Diet } \\
1\end{array}$ & $\begin{array}{l}\text { Diet } \\
2\end{array}$ & $\begin{array}{l}\text { Diet } \\
3\end{array}$ & $\begin{array}{l}\text { Diet } \\
4\end{array}$ & $\begin{array}{l}\text { Diet } \\
5\end{array}$ \\
\hline Barley & 38.00 & 38.00 & 38.00 & 38.00 & 37.00 \\
\hline Corn yellow & - & 10.00 & 10.00 & 15.00 & 20.00 \\
\hline Oats & 29.38 & 19.06 & 14.18 & 6.83 & 2.00 \\
\hline Wheat bran & 11.00 & 9.00 & 8.00 & 6.00 & 2.86 \\
\hline Soya bean meal ( $44 \%$ ) & 1.00 & 3.70 & 7.00 & 8.00 & 12.00 \\
\hline Fishmeal $\quad(65 \%)$ & 3.00 & 3.80 & 4.30 & 6.00 & 6.00 \\
\hline Lucerne meal & 5.00 & 3.00 & 3.00 & 3.00 & 2.00 \\
\hline Soya bean oil & 0.30 & 1.30 & 3.70 & 5.60 & 6.50 \\
\hline Calcium hydrogen & & & & & \\
\hline phosphate dihydrate ${ }^{1}$ & 1.70 & 1.70 & 1.60 & 1.40 & 1.50 \\
\hline Limestone & 8.80 & 8.70 & 8.60 & 8.60 & 8.60 \\
\hline Iodized salt & 0.50 & 0.50 & 0.50 & 0.50 & 0.50 \\
\hline Vitamin mineral mixture ${ }^{2}$ & 1.00 & 1.00 & 1.00 & 1.00 & 1.00 \\
\hline DL-Methionine $^{3}$ & 0.14 & 0.12 & 0.10 & 0.07 & 0.04 \\
\hline L-Lysine $\mathrm{e}^{3}$ & 0.18 & 0.12 & 0.02 & 0.00 & 0.00 \\
\hline TOTAL & 100.00 & 100.00 & 100.00 & 100.00 & 100.00 \\
\hline
\end{tabular}

1 Trivial name: dicalcium phosphate $\left(\mathrm{CaHPO}_{4} \cdot 2 \mathrm{H}_{2} \mathrm{O}\right)$.

2 Vitamin/mineral mixture contains in $1 \mathrm{~kg}$ : 900000 I.U. vitamin A; 180000 I.U. vitamin $\mathrm{D}_{3}$; 500 I.U. vitamin $\mathrm{E} ; 0.15 \mathrm{~g}$ vitamin $\mathrm{K}_{3} ; 0.1 \mathrm{~g}$ vitamin $\mathrm{B}_{1} ; 0.5 \mathrm{~g}$ vitamin $\mathrm{B}_{2} ; 0.1 \mathrm{~g}$ vitamin $\mathrm{B}_{6}$; $3 \mathrm{~g}$ nicotenic acid; $0.75 \mathrm{~g}$ D-pantothenic acid; $1 \mathrm{mg}$ vitamin $\mathrm{B}_{12} ; 50 \mathrm{mg}$ folic acid; $35 \mathrm{~g}$ choline chloride; $2 \mathrm{~g} \mathrm{Fe} ; 7 \mathrm{~g} \mathrm{Mn} ; 1 \mathrm{~g} \mathrm{Cu} ; 3 \mathrm{~g} \mathrm{Zn} ; 0.1 \mathrm{~g} \mathrm{I} ; 0.3 \mathrm{~g} \mathrm{Co}$.

3 Methionine and lysine have been added to cover the requirements.

Table 2. Calculated analysis of the experimental diets.

\begin{tabular}{|c|c|c|c|c|c|}
\hline Calculated analysis & $\begin{array}{l}\text { Diet } \\
1\end{array}$ & $\begin{array}{l}\text { Diet } \\
2\end{array}$ & $\begin{array}{l}\text { Diet } \\
3\end{array}$ & $\begin{array}{l}\text { Diet } \\
4\end{array}$ & $\begin{array}{l}\text { Diet } \\
5\end{array}$ \\
\hline Crude protein $(\mathrm{CP})(\%)$ & 12.0 & 12.9 & 14.04 & 15.02 & 15.97 \\
\hline $\mathrm{ME}(\mathrm{MJ} / \mathrm{kg})$ & 8.71 & 9.57 & 10.27 & 11.10 & 11.70 \\
\hline $\mathrm{ME} / \mathrm{CP}$ & 0.73 & 0.74 & 0.73 & 0.74 & 0.73 \\
\hline $\mathrm{Ca}(\%)$ & 3.70 & 3.73 & 3.68 & 3.72 & 3.71 \\
\hline Phosphorus available (\%) & 0.55 & 0.57 & 0.56 & 0.56 & 0.56 \\
\hline Crude fat $(\%)$ & 2.79 & 3.74 & 5.94 & 7.34 & 8.53 \\
\hline Crude fiber (\%) & 8.14 & 6.64 & 6.17 & 5.28 & 4.46 \\
\hline Methionine (\%) & 0.36 & 0.36 & 0.36 & 0.36 & 0.36 \\
\hline Meth. + cystine (\%) & 0.62 & 0.62 & 0.64 & 0.63 & 0.64 \\
\hline Lysine (\%) & 0.72 & 0.72 & 0.72 & 0.79 & 0.87 \\
\hline Isoleucine $(\%)$ & 0.49 & 0.54 & 0.60 & 0.66 & 0.72 \\
\hline Leucine $(\%)$ & 0.86 & 1.00 & 1.08 & 1.18 & 1.28 \\
\hline Phenylalanine + tyrosine $(\%)$ & 1.01 & 1.09 & 1.17 & 1.27 & 1.35 \\
\hline Tryptophan (\%) & 0.17 & 0.17 & 0.19 & 0.19 & 0.21 \\
\hline Valine (\%) & 0.66 & 0.71 & 0.77 & 0.81 & 0.86 \\
\hline Arginine (\%) & 0.71 & 0.75 & 0.85 & 0.90 & 0.97 \\
\hline Histidine (\%) & 0.27 & 0.30 & 0.33 & 0.36 & 0.38 \\
\hline Glycine (\%) & 0.57 & 0.61 & 0.65 & 0.71 & 0.74 \\
\hline
\end{tabular}

Neth. J. agric. Sci. 28 (1980) 
During 40 weeks of producting, starting from the age of 24 weeks when the birds showed about $60 \%$ production, daily egg production and egg weight were determined. Weekly feed consumption and conversion ( $\mathrm{kg}$ feed per $\mathrm{kg}$ egg) were calculated. Once a month body weight was measured and egg quality was tested. Eggs were collected from each experimental unit and the following data were sampled: egg weight, yolk weight, shell weight and albumen weight (by difference); percentages of total egg weight were calculated.

Data were submitted to a factorial analysis of variance and linear and quadratic components (Student $t$ test) were tested, and when applicable, treatment means were separated by Duncan's multiple-range test (1965).

\section{Results and discussion}

Egg production was not significantly affected by the several dietary treatments (Table 3). We observed only a slight increase in egg production with hens fed $14 \%$ $\mathrm{CP}$ and a slight decrease with $16 \%$.

Our results are in close agreement with Touchborn \& Naber (1962) who worked with diets of $12-20 \% \mathrm{CP}$ and a constant ratio of productive energy (MJ) to content of crude protein $(\%)$ of 0.55 (which corresponds to 0.80 for the ratio of metabolizable energy to crude protein), and found that egg production was not significantly affected by the nutrient density of the ration. Thornton \& Whittet (1959) showed that egg production in diets of $13 \% \mathrm{CP}$ was comparable to the 15 and $17 \% \mathrm{CP}$ with several levels of energy. De Groote (1972) working with diets of $14.3-18.3 \% \mathrm{CP}, 10.46-13.39 \mathrm{MJ} \mathrm{ME} / \mathrm{kg}$, a constant $\mathrm{ME}(\mathrm{MJ}) / \mathrm{CP}(\%)$ ratio of 0.73 , and Dillon (1974) working with diets of 14.2-17.4 \% CP, 11.30-13.81 $\mathrm{MJ} / \mathrm{kg}$, a ME $/ \mathrm{CP}$ ratio of 0.80 , reported that dietary protein and energy had no significant effect on egg production.

For mean egg weight, there was no significant differences with the several energy and protein treatments (Table 3). Our results are in close agreement with the work of Lillie \& Denton (1965), who pointed out that energy level (all protein levels

Table 3. Effect of levels of protein and energy (see Table 2) in rations on several performance characteristics.

\begin{tabular}{|c|c|c|c|c|c|}
\hline Parameter & $\begin{array}{c}\text { Diet } \\
1\end{array}$ & $\begin{array}{l}\text { Diet } \\
2\end{array}$ & $\begin{array}{l}\text { Diet } \\
3\end{array}$ & $\begin{array}{l}\text { Diet } \\
4\end{array}$ & $\begin{array}{l}\text { Diet } \\
5\end{array}$ \\
\hline Egg production $\%$ & 71.46 & 71.31 & 72.51 & 71.13 & 69.99 \\
\hline Mean egg weight (g) & 60.51 & 60.47 & 61.11 & 61.02 & 61.07 \\
\hline Feed consumption (g) & $157.16^{e}$ & $147.56^{\mathrm{d}}$ & $142.03 \mathrm{e}$ & $130.37 \mathrm{~b}$ & $126.72 \mathrm{a}$ \\
\hline Mean body weight (g) & $2901.6^{\mathrm{a}}$ & $2989.7 \mathrm{~b}$ & $3096.7 \mathrm{~d}$ & $3061.3 \mathrm{c}$ & $3086.3 \mathrm{~d}$ \\
\hline Feed conversion ( $\mathrm{kg}$ food $/ \mathrm{kg}$ eggs) & $3.674 \mathrm{~d}$ & $3.460 \mathrm{c}$ & $3.262^{b}$ & $3.031 \mathrm{a}$ & $3.014 \mathrm{a}$ \\
\hline Crude protein $(\mathrm{kg}) / \mathrm{egg}(\mathrm{kg})$ & $0.441 \mathrm{a}$ & $0.450 \mathrm{a}$ & $0.457 \mathrm{a}$ & $0.455 \mathrm{a}$ & $0.482 \mathbf{b}$ \\
\hline
\end{tabular}

Means with different subscripts horizontally are significantly different $(P<0.05)$ with Duncan's multiple range test. 
Table 4. Daily intake per hen of crude protein, energy, sulphur amino acids and lysine from the experimental diets (see Table 2).

\begin{tabular}{lccccc}
\hline & Diet 1 & Diet 2 & Diet 3 & Diet 4 & Diet 5 \\
& & & & & \\
Crude protein (g) & 18.86 & 19.18 & 19.88 & 19.56 & 20.28 \\
Metabolizable energy (MJ) & 1.369 & 1.412 & 1.459 & 1.447 & 1.483 \\
Methionine (mg) & 565.8 & 531.2 & 511.3 & 469.3 & 456.2 \\
Methionine + cystine (mg) & 974.4 & 914.9 & 909.0 & 821.3 & 811.0 \\
Lysine (mg) & 1131.6 & 1062.4 & 1022.6 & 1029.9 & 1102.5 \\
\hline
\end{tabular}

combined) had no effect on egg weight, while De Groote (1972) and Dillon (1974) came to contradictory results and showed that egg weight was significantly increased by increasing the energy and protein content of the ration. In general increased egg weight was a result of increased ME intake. Results in our trial differed in that the high energy consumed per bird was reflected in increase of body weight (Tables 3 and 4). El Boushy (1978) proved that egg weight was not significantly affected by increasing crude protein in isocaloric rations, but that work is not comparable with ours because we used diets with a constant energy protein ratio.

Feed consumption was highly significantly decreased with increasing dietary energy and protein (Table 3). The observed reduction in feed consumption appeared to be due to increasing the energy levels in the diets from $8.71 \mathrm{MJ} / \mathrm{kg} \mathrm{ME}$ and $12 \% \mathrm{CP}$ till $11.70 \mathrm{MJ} / \mathrm{kg} \mathrm{ME}$ and $16 \% \mathrm{CP}$. It is quite understandable that a high-energy ration is rich in carbohydrates and fat, which are more compact or of a high density and result in lower feed consumption. Thus diets with low energy are mostly high in crude fibre and more voluminous.

It seems that the birds (with low-energy low-protein diets) compensated their requirements of energy and protein with their high consumption and with extra sulphur amino acids and lysine (Table 4). Our results agree with the trend of findings by other workers, who pointed out that feed consumption was significantly decreased by increasing nutrient density, energy and protein (De Groote, 1972; Guenthner et al., 1972; Dillon, 1974).

Mean body weight was significantly increased by increasing the dietary energy and protein levels (Table 3). Birds receiving a diet rich in energy and protein will increase their body weight more than birds fed lower diets. The birds can consume a certain weight per day; if the density or energy is low, their feed consumption will increase to compensate their energy requirements. So, with high-density feed the input of energy per bird per day will be increased, as reflected on their fat deposition and an increase in body weight. Gleaves \& Dewan (1971) and De Groote (1972) observed the same trend for body weight to increase significantly as dietary protein and energy were increased.

Feed conversion was highly significantly improved by increasing the dietary levels of energy and protein (Table 3). Since egg production and egg weight were almost equal in all treatments and the only fluctuating variable was feed consumption, the picture of feed conversion is a clear reflection of feed consumption. 
Table 5. Effect of levels of protein and energy (see Table 2) in rations on proportion of egg components.

\begin{tabular}{lrrrrr}
\hline Parameter & Diet 1 & Diet 2 & Diet 3 & Diet 4 & Diet 5 \\
Egg weight (g) & 61.05 & 60.69 & 61.46 & 61.16 & 60.96 \\
Yolk (\%) & 27.78 & 27.73 & 27.64 & 27.32 & 27.63 \\
Albumen (\%) & 63.12 & 63.13 & 63.23 & 63.59 & 63.33 \\
Shell (\%) & 9.10 & 9.14 & 9.13 & 9.09 & 9.04 \\
\hline
\end{tabular}

Analysis of variance and Student $t$ test did not show any significant differences.

Our results showed the same trend as those of Touchburn \& Naber (1962), who showed that the efficiency of feed utilization increased as the nutrient density increased, while Guenthner et al. (1972) reported that increasing the energy level improved feed conversion which was not significantly influenced by the levels of protein used.

Egg quality as measured by egg weight $(\mathrm{g})$ and proportions of yolk, albumen and shell did nod show any significant difference among the several treatments (Table 5). Gardner \& Young (1972) concluded that increasing dietary energy and protein resulted in an increase in yolk weight. In our trial the energy consumed per bird was not reflected on the yolk percentage, but the high energy intake resulted in more fat deposition and increased body weight.

Dillon (1974) reported that albumen quality (Haugh units) was not significantly affected by dietary energy and protein levels. The albumen weight absolutely or relatively is highly correlated with egg weight. Since egg weight was not affected by the several treatments, it was normal that albumen percentage did not show any deviations. El Boushy (1978) showed with isocaloric diets and increasing protein levels that yolk percentage did not show any significant difference.

\section{References}

Aitken, J. R., G. E. Dickerson \& R. S. Gowe, 1973. Effect of intake and source of protein on laying performance of seven strains under single and double cage housing. Poultry Sci. 52: 2127-2134.

De Groote, G., 1972. A marginal income and cost analysis of the effect of nutrient density on the performance of white leghorn hens in battery cages. Br. Poultry Sci. 13: 503-520.

Dillon, J. F., 1974. Energy intake regulation by layers according to diet, productivity and environment. Aust. J. Exp. Agric. Animal Husb. 14 (67): 133-140.

Duncan, D. B., 1965. Multiple range and multiple F-tests. Biometrics 11: 1-42.

El Boushy, A. R. \& I. Muilwijk, 1978. Effect of varied protein levels with synthetic amino acids on performance of layers and egg quality. Feedstuffs 50 (44): 15-16, 50.

Fernandez, P., A. J. Salman \& J. McGinnis, 1973. Effect of feeding different protein levels and of changing protein level on egg production. Poultry Sci. 52: 64-69.

Gardner, F. A. \& L. L. Young, 1972. The influence of dietary protein and energy levels on the protein and lipid content of the hen's egg. Poultry Sci. 51: 994-997. 
Gleaves, E. W. \& S. Dewan, 1971. The influence of dietary and environmental factors upon feed consumption and production responses in laying chickens. Poultry Sci. 50: 46-55.

Gleaves, E. W., L. V. Tonkinson, J. D. Wolf, C. K. Harman, R. H. Thayer \& R. D. Morrison, 1968. The action and interaction of physiological food intake regulators in the laying hen. 1. Effects of dietary factors upon feed consumption and production responses. Poultry Sci. 47: 38-67.

Guenthner, E., D. Arshem \& C. W. Carlson, 1972. Protein-energy levels and least cost laying diets. Poultry Sci. 51: 1813-1814.

Johnson, D., Jr. \& H. Fisher, 1959. The amino acid requirement of laying hens. 4. Supplying minimal levels of essential amino acids from natural feed ingredients. Poultry Sci. 38: 149152.

Lillie, R. J. \& C. A. Denton, 1965. Protein and energy interrelationships for laying hens. Poultry Sci. 44: 753-761.

Morris, T. R., 1968. The effect of dietary energy level on the voluntary calorie intake of laying birds. Br. Poultry Sci. 9: 285-295.

Quisenberry, J. H., 1965. Phase feeding of laying hens. Feedstuffs 37 (24): 51-54.

Reid, B. L., 1976. Estimated daily protein requirements of laying hens. Poultry Sci. 55: 16411645.

Smith, R. E., 1965. Alteration of protein level in laying rations at various stages within the laying cycle and its effect upon performance of laying hens. Can. J. Anim. Sci. 45: 211-215.

Student $t$ test, 1975. Statistical package for the social sciences, 2nd ed. McGraw-Hill, New York.

Thornton, P. A. \& W. Whittet, 1959. The adequacy of low protein levels for egg production under various conditions. Poultry Sci. 38: 1255.

Touchburn, S. P. \& E. C. Naber, 1962. Effect of nutrient density and protein-energy interrelationships on reproductive performance of the hen. Poultry Sci. 41: 1481-1488. 